Електронне наукове фахове видання «Адаптивне управління: теорія і практика. Серія «Педагогіка»

УДК $352 / 354$

https://doi.org/10.33296/2707-0255-11(21)-10

КОВРИГА ОЛЕНА

Кандидат наук з державного

управління, доцент, доцент кафедри менеджменту

освіти та права,

Центральний інститут післядипломної

Освіти,

Університет менеджменту освіти

м. Київ, Україна

https ://orcid.org/0000-0001-6220-3477

\title{
ОСНОВНІ СУТНІСНІ ХАРАКТЕРИСТИКИ ДЕРЖАВНОЇ МОЛОДІЖНОї ПОЛІТИКИ
}

Анотація. У статті розкрито сутнісні характеристики державної молодіжної політики, узагальнено основні етапи формування та еволюції державної політики за підтримки розвитку молоді. Зазначено історичний аспект походження й впровадження державної молодіжної політики на вищому владному рівні у вигляді структур й органів, які займаються іiі розробкою та координацією. Окреслені поняття «молодь» i «політика», як складові поняття «молодіжної політики». Висвітлено суб'єкт і об'єкт у сфері підтримки молоді на державному рівні, основну мету і завдання. Визначено, що мета державної молодіжної політики сприймається як реалізація всебічних, послідовних та взаємно-узгоджених заходів органів державної влади, органів місцевого самоврядування та неурядових організацій, які активно представляють інтереси молодого покоління, в процесі формування державної молодіжної політики, а також реалізація та створення соціально-економічних, політичних, організаційних та законодавчих умов у сприянні розвитку освіти, зайнятості, ініціативам, творчій та інноваційній діяльності молоді.

Державну молодіжну політику прийнято визначати пріоритетним i специфічним напрямом діяльності держави, який здійснюється в інтересах молодої людини, суспільства, держави та 3 урахуванням державних можливостей, іiі економічного, соціального, історичного, культурного розвитку і світового досвіду державної підтримки молоді. Підтримка молоді відбувається системно, у співвідносинах між державою та молодим поколінням, молодіжними угрупуваннями чи однією особистістю. Реалізується в діяльності усіх гілок влади (законодавчої, виконавчої, судової), 3 метою надання соціально-економічних, політичних, організаційних, правових умов та гарантій для життєвого самовизначення молоді й реалізації усіх їхніх цілей і потреб.

(C) Українська інженерно-педагогічна академія

(C) ГО «Школа адаптивного управління соціально-педагогічними системами»

(C) Коврига О. 
Зазначено, що в сучасних умовах розвитку, покладаючись на Європейський досвід i практики, державна молодіжна політика України вимагає невідкладного впровадження і практичної реалізації комплексу заходів, в особливості стосовно всіх проблемних питань із зайнятості, надання рівних можливостей на ринку праці, підвищення рівня оплати праці, сприяння у розвитку малого бізнесу тощо. Тож, розв'язання усіх проблем молоді ключовий момент в реалізації державної молодіжної політики, а належне іiі виховання - перспектива результативності державної молодіжної політики.

Ключові слова: молодь, політика, молодіжна політика, державна молодіжна політика, суб'єкти реалізації державної молодіжної політики, об’єкти державної молодіжної політики, мета та завдання державної молодіжної політики, впровадження молодіжної політики.

Актуальність дослідження і постановка проблеми. Підтримка молоді в процесі формування державної молодіжної політики займає пріоритетне місце в сучасних реаліях, адже кожна сфера суспільно-політичної діяльності стосується молоді та її вкладу в розвиток держави.

Державна молодіжна політика в Україні є пріоритетним і специфічним напрямом діяльності держави і здійснюється: в інтересах молодої людини, суспільства, держави, з урахуванням можливостей України, її економічного, соціального, історичного, культурного розвитку і світового досвіду державної підтримки молоді. Підтримка молодіжного потенціалу є важливою складовою системної діяльності держави, оскільки саме молодь дає надію на краще майбутнє, допомагає своїми ідеями, інтелектуальними ініціативами й проектами вибратися 3 кризи й підняти рівень успішності України на міжнародній арені.

Аналіз досліджень та публікацій. До аналізу проблематики щодо впровадження та регулювання державної політики розвитку підтримки молоді зверталися вчені та фахівці різних наукових галузей: С. Злупко,
В. Васильченко,
В. Петюх,
М. Махсма,
Р. Шабанов
В. Андрущенко,
Г. Берегова, Д. Дзвінчук, П. Дракер, М. Згуровський, В. Зінченко, К. Корсак, О. Голобуцький, $\quad$ В. Даніл'ян, А. Колодюк, В. Лях, Є. Макаренко, 
О. Маруховський, В. Руденко, О. Шевчук, А. Ярошенко, М. Михальченко, А. Новіков, А. Сбруєва, Ф. Уебстер, С. Бородін, М. Головатий та ін. Але, дана тема є актуальною й потребує детального розгляду.

Мета статті полягає в дослідженні теоретичних напрацювань щодо основних сутнісних характеристик державної молодіжної політики, етапів формування державної політики забезпечення розвитку молоді в світі та України та визначенні напрямів удосконалення молодіжної політики.

Виклад основного матеріалу. Вперше молодіжна політика почала проявлятися у XIX столітті на заходах, які організовувала державна влада на підтримку неповнолітнім дітям, які працюють. Такі заходи не представляли собою окремої галузі політики, але з часом розширились і нині становлять цілу систему по вирішенню конфліктних ситуацій у суспільстві [13].

Фактично, як цілісна система, «державна молодіжна політика» почала впроваджуватися у 1920-тих роках. ІІЇ базове підгрунтя започаткувало створення двох систем. Перша система базувалася на соціальній педагогіці провідної правової держави Німеччини. Друга символізувала інструмент для реалізації ідеології правлячої партії комсомол у Радянському Союзі [13].

У 1950-1960-х роках «молодіжна політика» набуває поширення серед суспільно-політичної літератури. Починається різке зростання зацікавленості молоді соціально-політичною діяльністю, що виокремлює ï як самостійну соціальну силу 3 їі самовизначенням та самовдосконаленням в суспільнополітичному просторі [10].

3 1970-х років молодіжна політика стає самостійним напрямом державної влади в більшості провідних країн світу. Саме $з$ того часу почалося масове прийняття законодавчих документів, спеціальних програм у напрямку реалізації прав молоді з питань працевлаштування та надання освіти, а також належне вирішення проблемних питань молодих сімей. Представники Організації Об'єднаних Націй (ООН) стверджують, що на початку 1990-х років, 
в усьому світі більше ніж 100 країн прийняли закони, які стосувалися питань соціальної захищеності й розвитку молодих людей. Приблизно 90 країн створили на вищому владному рівні структури й органи, які займаються розробкою та координацією державної молодіжної політики [10].

Зазначимо, що вже з 1992 року під визначенням «державна молодіжна політика» прийнято вважати - системну діяльність держави у відносинах 3 певною особистістю, молоддю, молодіжними рухами та здійснюється в законодавчій, виконавчій, судовій сферах, i ставить метою створення політичних, соціально-економічних, організаційних, правових благ та гарантій для життєвого самовизначення, інтелектуальної, моральної, фізичної самореалізації здібностей молоді, розвиток іiі творчості й потенціалу як у власних інтересах, так і в інтересах українського народу й держави [4].

Луценко С. стверджує, що молоде покоління завжди проявляло активістські здібності й залізну наполегливість, воно легке в комунікаціях й відкрите до будь-яких перетворень [8].

Оскільки основою сфери державної молодіжної політики є молоде покоління, варто розглянути його, як окрему складову цього поняття.

У словнику-довіднику соціального працівника прописано, що «молодь $\epsilon$ соціально-демографічною групою, iї специфічні соціальні і психологічні межі зумовлені віковими особливостями, процесом становлення їх духовного світу, специфікою положення в соціальній структурі суспільства» [6]. Це поняття підкреслює психологічні й соціально-патріотичні особливості кожного індивіда.

В окремих аналітичних доповідях зауважують, що вікове залучення молоді до активістських програм на території України обмежується станом до 28-ми років, проте деякі зацікавлені громадські організації чи активістські групи можуть продовжити вікове обмеження, в залежності від тематики проектів й досвідченості спеціалістів. Основним показником, за яким 
визначають амбіційну молодь, як соціально-демографічну групу, є не лише вікові межі, але й місце, яке вона посідає в суспільстві, пї соціальну зацікавленість, готовність до змін й відстоювання позицій [12].

Вікові межі постійно вивчалися багатьма дослідниками не лише у сфері психології, соціології, а й мали пряме відношення до напрямів державотворення, зокрема розглядалася проблематика важливості й складності особистостей. М. Головатий стверджував, що вікове обмеження молодого покоління $\epsilon$ не лише предметом для наукових дискусій. Він вважав, що кінцевою межею є той момент, коли людина здобуває економічну незалежність, бере участь у створенні матеріальних та духовних цінностей $\mathrm{i}$ готова продовжувати свій рід. Враховуючи усі аспекти, науковець дійшов висновку, що неможливо розглядати кожну умову поодинці, а лише в тісній взаємозалежності без жодної ідеалізації [13].

У підручниках сказано, що політика, як друга необхідна складова поняття «молодіжної політики», має багато значень, проте найбільш відповідне визначення до даної теми тлумачить ऑї, як одну 3 найважливіших сфер життєдіяльності суспільства, взаємовідносин різних соціальних груп та індивідів щодо утримання й реалізації влади задля здійснення своїх суспільно значущих інтересів і потреб, вироблення обов'язкових для всього суспільства рішень [3].

Сторожук Р. зазначає, що складність структури молодіжної політики на державному рівні проявляється у наступних особливостях: організаційна спроможність амбіційних організацій, координуючі й керівні органи у виконанні молодіжної політики, управлінсько-виконавча структура для ii реалізації, система фінансування та важливість надання й розподілу коштів суб'єктами державної молодіжної політики, а також пильне контролювання цього процесу [11]. 
Електронне наукове фахове видання «Адаптивне управління: теорія і практика.

У «Політологічному енциклопедичному словнику» вказано, що суб'єктами реалізації державної молодіжної політики на території України є власне сама держава, ii виконавчі органи влади, політичні партії, громадські організації, об’єднання, профспілки, соціальні інститути, які приймають участь у реалізації з питань науки, освіти, культури, окремі групи й громадяни, інші структури політичної системи суспільства [14].

Метьолкіна Н. визначає, що об’єктом державного управління є молодь, віком від 14 до 35років, молодіжні угрупування й об'єднання, а також процеси, які відбуваються в молодіжному середовищі, відносини у кожній сфері життєдіяльності молоді, які пильно контролюються, організовуються й координуються певними суб'єктами молодіжної політики [9].

Суб'єкт і об'єкт, зазначає автор у своєму дослідженні, у сфері підтримки талановитої молоді тісно взаємодіють у процесі управлінської діяльності для досягнення цілей державної молодіжної політики, які формують створення соціально-економічних, політичних, організаційних, правових умов та гарантій для життєвого самовизначення, інтелектуального, морального, фізичного розвитку молодого покоління, реалізації творчого потенціалу як у його власних інтересах, так і в інтересах України [9].

Спираючись на вищезазначені твердження, можна виділити основну мету державної молодіжної політики:

- гарантія у забезпеченні належної рівності прав, обов'язків і соціальних перспектив для молодих активістів, у співпраці з іншими соціальними групами, проте не за їх кошти;

- соціальна захищеність молоді, гарантія вирішення виникаючих соціально-політичних, економічних, духовних проблем, а також така захищеність має поєднувати в собі надання можливостей для створення життєво необхідних належних можливостей для початкового влаштування власного життя, адаптації в ньому, саморозвитку і самореалізації;

(C) Українська інженерно-педагогічна академія

(C) ГО «Школа адаптивного управління соціально-педагогічними системами»

(C) Коврига О. 
- заохочення й підтримка основних державно-корисних ініціатив молодих активних спеціалістів, їх угрупувань і рухів, які мають на меті зробити визначний внесок у знаходженні компромісу між активістами однодумцями, а також у вирішенні загальних проблем [8].

Основні завдання державної молодіжної політики включають:

- по-перше, приділення детальної уваги до становища молодих спеціалістів, створення необхідних умов для удосконалення й зміцнення нормативно-правових та матеріальних гарантій щодо здійснення прав і свобод молоді, діяльності молодіжних гуртків чи організацій для їхнього повноцінного становлення та розвитку в соціумі;

- по-друге, надання допомоги молодіжним рухам у реалізації й самовдосконаленні їх творчих навиків та можливостей, масштабне залучення школярів, підлітків, студентства, молодих та амбіційних лідерів до активної участі у національно-культурному відродженні української народності, традицій, українського духу, формуванні його свідомості й розвитку національно-етнічних особливостей;

- по-третє, залучення молодих спеціалістів до активної участі в економічній сфері розвитку України;

- по-четверте, забезпечення державою кожній молодій амбіційній особистості соціальних послуг по навчанню, вихованню, духовному i фізичному розвитку, професійній підготовці;

- по-п'яте, скоординовану працю всіх організацій, державних та соціальних інститутів, які працюють 3 молоддю [4].

Завдання, спрямовані на подолання перешкод у реалізації державної молодіжної політики, виконуються шляхом: консолідації зусиль, що спрямовані на забезпечення сприятливих умов для інтелектуального, морального та фізичного розвитку молодого покоління, реалізація його освітнього та творчого потенціалу; забезпечення участі молодих людей у процесі формування 
державної молодіжної політики; підвищення ефективності реалізації державної молодіжної політики на національному, регіональному та місцевому рівнях тощо [4].

Підкреслюємо, що державна молодіжна політика в Україні формується та реалізується через: рішення органів державної влади, законодавчі акти, які спрямовані на реалізацію державної молодіжної політики; діяльність і вплив державних органів та управління усіх рівнів структурних підрозділів, які займаються проблемами молодої верстви населення; проведення Верховною Радою України регулярних слухань про стан і розвиток молодого покоління, а також підготовки виступів з доповідями Верховній Раді України, Президенту України, які стосуються даної теми; утворення соціальних підрозділів для молодих людей та підготовка соціальних робітників; через впровадження та реалізацію цільових програм 3 важливих питань державної молодіжної політики; цілеспрямовано виділення кошів з державного та місцевого бюджетів на реалізацію потреб молодіжної політики, забезпечення матеріальними i фінансовими ресурсами 3 підприємств, установ та організацій, об'єднань громадського сектору, які зацікавлені у співпраці з молодим поколінням; утворення спеціальних фондів [4].

Варто наголосити, що питанням впровадження молодіжної політики займалися велика кількість вчених, філософів, соціологів та спеціалістів у сфері відродження українського духу й національності амбіційними молодими руками. Зокрема, відомий соціолог, спеціаліст в області соціології молоді та молодіжної політики, філософії й соціології освіти І. Ільїнський [7].

У своїх працях дослідник зазначає, що молодіжна політика має два значення, у першому випадку, вона являє собою систему ідей, теоретичних положень про роль і місце молоді в соціалістичному суспільстві; в іншому значенні - це цільова практична політична діяльність таких державних суб'єктів, як: держави, партій, громадських організацій та інших соціальних 
інститутів щодо реалізації положень, ідей і директив, з метою формування і розвитку, реалізації іiі творчих потенцій в інтересах будівництва нового суспільства [2, с. 28].

Зазначимо, що теоретично він поділяє політику на два напрями: суспільну й державну молодіжну політику. До суспільної молодіжної політики соціолог відносить - систему ідей, поглядів, направлених від молодих обдарованих людей, та iї ролі в суспільному розвитку, а також практичних діянь різних організацій громадянського суспільства, які націлені на впровадження ціннісних поглядів та ідей у життя, 3 метою досягнення суспільних перспектив [5, с. 347].

Таким чином, ми бачимо, що свою результативність державна молодіжна політика приносить виключно за належного виховання молоді, поступового формування іï світогляду й об'єктивного сприйняття дійсності. Тому підтримка молодого покоління з боку держави має велике значення у процесі формування й розвитку кожної особистості [8].

Крім того, вважаємо, що саме в період проведення реформ варто давати молоді більше ініціювань, прийняття рішень, співучасті у важливих заходах, висловлення своїх думок, хоча б на волонтерських засадах, бо саме через практику набувається досвід. А найталановитіших нагороджувати й виділяти, можливо такі люди є перспективними і в майбутньому принесуть чималі досягнення на користь держави та ï державотворчих процесів.

Отже, підводячи підсумок проведеного дослідження, хотілося б наголосити на важливості підтримки молодіжного потенціалу та ініціатив зі сторони органів державної влади та органів місцевого самоврядування. Говорячи про ініціативи, підкреслюємо, що підтримку нових ідей досить важко отримати зі сторони органів державної влади, тому молодим людям доводиться залучати інші способи для підтримки і розвитку тих чи інших проектів, віднаходити спонсорів не байдужих благодійників тощо. Такий підхід зі 
сторони державних органів руйнує довіру й сосунки з громадянами зсередини країни. Така ситуація змушує молодь не лише менше цікавитися політикою, а й довіряти політикам взагалі.

Таким чином, варто зазначити, що результати наукових досліджень, нормативно-правові акти, які стосуються сфери забезпечення розвитку та підтримки талановитої молоді України, повинні реалізовуватися на основі безпосереднього реформування системи державної політики, для підвищення іміджу та значущості українських талантів, як серед провідних країн світу, так $і$ в першу чергу в середині країни.

Висновки. Тож, на основі вищезазначеного, можна зробити висновок, що держава розглядає молодь України як дієздатну й ефективну верству населення, яка має потенціал для залучення нового творчого духу в межі країни. Потенціал молоді може бути більш потужним та дієвим, за умови застосування активних підходів до навчання та роботи 3 нею, держава має визнавати іï за партнерів у процесі свого розвитку. Активне включення молодої верстви населення до сфери молодіжної політики приведе до набуття нею всеосяжного характеру.

\section{СПИСОК ВИКОРИСТАНИХ ДЖЕРЕЛ}

1. Балакірєва О. М., Головенько В. А.Державна молодіжна політика як важливий напрям діяльності владних інститутів щодо розв'язання проблем молоді в сучасній Україні. Укр. соціум, 2006. № 6. С. 149-150.

2. Бородін Є.І. Історія формування державної молодіжної політики в Україні (1991-2004 рр.): Монографія. Д.: Герда, 2006. 472 с.

3. Горбатенко В.П., Бабкіна О.В. Політологія: підручник. Політика, як соиіальне явище. Київ: ВЦ «Академія», 2003. 528c.

4.Декларація «Про загальні засади державної молодіжної політики в Україні від 03.03.2006, підстава - 3421-IV». URL: http://zakon.rada.gov.ua/laws/show/2859-12.

5. Донченко Т.О. Формування державної молодіжної політики в Україні: історико-правовий аспект. 2009. С.2-5.

6. Кизименко Л.Д., Бєдна Л.М. Словник-довідник соціального працівника. URL: http://ipp.lp.edu.ua/Library/004/004.html 
7. Луков В.А. Молодежная политика: концепция И.М. Ильинского. Москва: МГУ, 2016. С.1-12.

8. Луценко С.М. Особливості реалізації молодіжної політики в Україні та за кордоном: управлінський аспект. Суми: СОІППО, 2016. С. 157-165.

9. Метьолкіна Н.Б. Механізми формування та реалізації державної молодіжної політики в Україні. Харків: ХарРІНАДУ, 2008. 11с.

10. Скробов А. П. О некоторых нових подходах к молодежной политике в условиях реформ. Социально-политический журнал. 1998. № 3. С. 129-140.

11.Сторожук Р.П. Державна молодіжна політика в контексті європейського вибору України: механізми: автореф. дис. Одеса, 2007. 23 с.

12. Участь молоді в суспільному житті: досвід, можливості, бар'єри. Щорічна доповідь Президенту Украйни, Верховній Раді Украӥни, кабінету Міністрів України про становище молоді в Украӥні (за підсумками 2011 року) Міністерство освіти і науки, молоді та спорту України, Державна служба молоді та спорту України. К.: 2012. 222 с.

13. Цибін С.Г. Молодіжна політика, як предмет наукового осягнення. Нова парадигма, випуск 91, 2009. С. 147-155.

14.Шевчук Ю.С. Бабкін В.Д. Горбатенко В.П. Політологічний енциклопедичний словник. К.: «Генеза», 2004. 735с.

\section{REFERENCES}

1. Balakireva O.M., Golovenko V.A. State youth policy as an important activity of government institutions to solve youth problems in modern Ukraine. Ukr. society, 2006. № 6. pp. 149-150.

2. Borodin E.I. History of the formation of state youth policy in Ukraine (19912004): Monograph. D .: Gerda, 2006. 472 s.

3. Gorbatenko V.P., Babkina O.V. Political Science: a textbook. Politics as a social phenomenon. Kyiv: VC "Academy", 2003. 528p.

4. Declaration "On the general principles of state youth policy in Ukraine dated 03.03.2006, basis - 3421-IV". URL: http://zakon.rada.gov.ua/laws/show/2859-12.

5. Donchenko T.O. Formation of the state youth policy in Ukraine: historical and legal aspect. 2009. P.2-5.

6. Kizimenko L.D., Bedna L.M. Dictionary-reference book of a social worker. URL: http://ipp.lp.edu.ua/Library/004/004.html

7. Lukov V.A. Youth policy: the concept of IM Ильинского. Moscow: Moscow State University, 2016. P.1-12.

8. Lutsenko S.M. Peculiarities of youth policy implementation in Ukraine and abroad: managerial aspect. Sumy: SOIPPO, 2016. S. 157-165.

9. Metolkina N.B. Mechanisms of formation and implementation of state youth policy in Ukraine. Kharkiv: HarRINADU, 2008. 11p.

10. Skrobov A.P. On some new approaches to youth policy in the context of reforms. Socio-political magazine. 1998. № 3. pp. 129-140.

(C) Українська інженерно-педагогічна академія

(C) ГО «Школа адаптивного управління соціально-педагогічними системами»

(C) Коврига О. 
11. Storozhuk R.P. State youth policy in the context of the European choice of Ukraine: mechanisms: author's ref. dis. Odessa, 2007. 23 p.

12. Youth participation in public life: experience, opportunities, barriers. Annual report to the President of Ukraine, the Verkhovna Rada of Ukraine, the Cabinet of Ministers of Ukraine on the situation of youth in Ukraine (following the results of 2011) Ministry of Education and Science, Youth and Sports of Ukraine, State Service of Youth and Sports of Ukraine. K .: 2012. $222 \mathrm{~s}$.

13. Tsibin S.G. Youth policy as a subject of scientific comprehension. New Paradigm, Issue 91, 2009. pp. 147-155.

14. Shevchuk Yu.S. Babkin V.D. Gorbatenko V.P. Political science encyclopedic dictionary. K .: "Genesis", 2004. 735p.

\section{КОВРИГА ЕЛЕНА}

кандидат наук по государственному

управлению, доцент, доцент кафедры менеджмента

образования и права,

Центральный институт

последипломного образования,

Университет менеджмента образования

м. Киев, Украина

\section{ОСНОВНЫЕ СУЩНОСТНЫЕ ХАРАКТЕРИСТИКИ ГОСУДАРСТВЕННОЙ МОЛОДЕЖНОЙ ПОЛИТИКИ}

Аннотация. В статье раскрыто сущностные характеристики государственной молодежной политики, обобщены основные этапы формирования и эволюции государственной политики при поддержке развития молодежи. Указано исторический аспект происхождения и внедрение государственной молодежной политики на высшем властном уровне в виде структур и органов, занимающихся ее разработкой и координацией. Указанные понятия «молодежь» и «политика», как составляющие понятия «молодежной политики». Освещены субъект и объект в сфере поддержки молодежи на государственном уровне, основную цель и задачи. Определено, что цель государственной молодежной политики воспринимается как реализация всесторонних, последовательных и взаимно согласованных мероприятий органов государственной власти, органов местного самоуправления и неправительственных организаций, которые активно представляют интересы молодого поколения, в процессе формирования государственной молодежной политики, а также реализация и создание социально экономических, политических, организационных и законодательных условий в содействии

(C) Українська інженерно-педагогічна академія

(C) ГО «Школа адаптивного управління соціально-педагогічними системами»

(C) Коврига О. 
развитию образования, занятости, инициативам, творческой и инновационной деятельности молодежи.

Государственную молодежную политику принято определять приоритетным и специфическим направлением деятельности государства, которая осуществляется в интересах молодого человека, общества, государства с учетом государственных возможностей ее экономического, социального, исторического, культурного развития и мирового опыта государственной поддержки молодежи. Поддержка молодежи происходит системно, в соотношении между государством и молодым поколением, молодежными группировками или одной личностью. Реализуется в деятельности всех ветвей власти (законодательной, исполнительной, судебной), с целью предоставления социально-экономических, политических, организационных, правовых условий и гарантий для жизненного самоопределения молодежи и реализации всех своих целей и потребностей. Отмечено, что в современных условиях развития, полагаясь на Европейский опыт и практики, государственная молодежная политика Украины требует безотлагательного внедрения и практической реализации комплекса мероприятий, в особенности по решению всех проблемных вопросов по занятости, предоставления равных возможностей на рынке труда, повышение уровня оплаты труда, содействие в развитии малого бизнеса и тому подобное. Поэтому, решение всех проблем молодежи ключевой момент в реализации государственной молодежной политики, а должное его воспитание - перспектива результативности государственной молодежной политики.

Ключевые слова: молодежь, политика, молодежная политика, государственная молодежная политика, субъекты реализации государственной молодежной политики, объекты государственной молодежной политики, цели и задачи государственной молодежной политики, внедрение молодежной политики.

\section{KOVRIGA OLENA}

Candidate of Sciences in Public

Administration, Associate Professor, Associate Professor of the Department of Education and Law Management, Central Institute of Postgraduate Education, University of Education Management Kyiv, Ukraine

\section{THE MAIN ESSENTIAL CHARACTERISTICS OF THE STATE YOUTH POLICY}


Abstract. The article reveals the essential characteristics of state youth policy, summarizes the main stages of formation and evolution of state policy in support of youth development. The historical aspect of the origin and implementation of the state youth policy at the highest level of government in the form of structures and bodies engaged in its development and coordination is indicated. The concepts of "youth" and "politics" are outlined as components of the concept of "youth policy". The subject and object in the field of youth support at the state level, the main purpose and objectives are highlighted. It is determined that the goal of state youth policy is perceived as the implementation of comprehensive, consistent and mutually agreed measures of public authorities, local governments and non-governmental organizations that actively represent the interests of the younger generation in the formation of state youth policy, as well as implementation and creation of social economic, political, organizational and legislative conditions in promoting education, employment, initiatives, creative and innovative activities of young people.

State youth policy is defined as a priority and specific direction of the state, which is carried out in the interests of young people, society, state and taking into account state opportunities, its economic, social, historical, cultural development and world experience of state support for youth. Youth support takes place systematically, in the relationship between the state and the younger generation, youth groups or individuals. Implemented in the activities of all branches of government (legislative, executive, judicial), in order to provide socio-economic, political, organizational, legal conditions and guarantees for the vital self-determination of young people and the realization of all their goals and needs. It is noted that in modern conditions of development, relying on European experience and practice, the state youth policy of Ukraine requires immediate implementation and practical implementation of a set of measures, especially to address all employment issues, provide equal opportunities in the labor market, increase wages, assistance in small business development, etc. Therefore, solving all the problems of youth is a key moment in the implementation of state youth policy, and its proper education is a prospect for the effectiveness of state youth policy.

Key words: youth, policy, youth policy, state youth policy, subjects of realization of the state youth policy, objects of the state youth policy, the purpose and tasks of the state youth policy, implementation of the youth policy. 